\title{
Chemical Quality of Broiler Chicken Rations in Finisher Phase Containing Fermented Bean Sprout Waste Flour
}

\author{
Ni Ketut Mardewi*, Ni Ketut Sri Rukmini, I Gst. A. Dewi Seri Rejeki \\ \{mardewiketut8@gmail.com* \\ Universitas Warmadewa, Bali, Indonesia
}

\begin{abstract}
Green bean sprout waste is obtained from its production with the basic ingredients and sellers. This waste product is one of the potential ingredients in broiler chicken ration and a source of vegetable protein. However, the fiber and protein contents of bean sprouts are high, and therefore need to be fermented to improve digestibility and nutritional quality. This research, therefore, aims to determine the nutrient content of broiler chicken rations in the finisher phase containing fermented bean sprouts waste flour by proximate analysis in the laboratory. This study was conducted using a Completely Randomized Design (CRD) with 4 treatments and 3 replications. The treatments consisted of rations without fermented bean sprouts waste flour (TLTF) (P0), $3 \%$ TLTF (P1), 6\% TLTF (P2), and 9\% TLTF (P3). The variables analyzed were crude protein, fiber, and fat of the ration. The results of this study showed that the provision of fermented bean sprouts wastes flour for broiler chicken ration in the finisher phase significantly affected $(\mathrm{P}<0.05)$ the variables of protein, fiber, and fat. In conclusion, an increase of crude protein and fiber in broiler chicken rations with $6 \%$ TLTF was the closest to the standard requirement in the finisher phase.
\end{abstract}

Keywords: Broiler Chicken, Chemical Quality, Bean Sprouts Waste

\section{Pendahuluan}

Ransum adalah bahan jadi yang merupakan campuran beberapa bahan pakan yang diberikan kepada ternak untuk memenuhi kebutuhan satu hari bagi berbagai fungsi tubuhnya, seperti hidup pokok, produksi maupun reproduksi. Ransum mengandung beberapa zat makanan meliputi air, energi, lemak, protein, mineral dan vitamin (Rahayu, 2010). Nutrien yang terkandung di dalam ransum yang sesuai kebutuhan ternak akan menunjang produktivitas yang baik. Kebutuhan nutrisi ayam broiler fase finisher meliputi Energi Termetabolis (ME) minimal $2900 \mathrm{kkal} / \mathrm{kg}$, Protein minimal 18\%, Lemak maksimal 8\%, Serat Kasar maksimal 6\%, Ca 0,9-1,2\% dan P 0,6-1,0\% [1] dan [2].Limbah tauge tersedia cukup banyak, tapi pemanfaatannya untuk bahan penyusun ransum ayam masih terbatas [3]. Limbah tauge kacang hijau mempunyai kadar protein kasar dan serat kasar yang tinggi. Pemakaian limbah tauge dalam ransum ayam broiler sebagai salah satu sumber protein nabati. Namun 
kadar serat kasar yang tinggi yang terkandung dalam limbah tauge kacang hijau dapat menurunkan kecernaan dan produktivitas ternak [4]. [5] menyatakan kandungan protein dan serat kasar limbah tauge kacang hijau adalah $13,60 \%$ dan 49,44\%. Kadar serat kasar limbah tauge harus diturunkan melalui proses fermentasi. Sebagai penilaian kualitas ransum, terutama pada standar zat makanan yang seharusnya terkandung di dalamnya, digunakan uji kimia. Pengujian ransum dengan uji kimia akan mendapatkan data yang pasti mengenai kandungan nutrisi dari ransum yang dibuat untuk ayam broiler fase finisher. Berdasarkan uraian di atas, maka perlu dilakukan penelitian untuk menguji kualitas kimia ransum yang mengandung tepung limbah tauge kacang hijau fermentasi untuk ayam broiler fase finisher.

\section{Metode Penelitian}

\subsection{Lokasi Dan Waktu Penelitian}

Penelitian dilakukan di Laboratorium Ilmu Dasar Fakultas Pertanian Universitas Warmadewa dan di Laboratorium Nutrisi dan Makanan Ternak Universitas Udayana Denpasar. Penelitian dimulai pada bulan Mei 2019 dan berakhir bulan Desember 2019.

\subsection{Metode Penelitian}

Penelitian menggunakan Rancangan Acak Lengkap dengan 4 perlakuan dan 3 kali ulangan pada masing-masing perlakuan. Perlakuan yang diterapkan adalah $\mathrm{P} 0=$ ransum tanpa kandungan tepung limbah tauge fermentasi (TLTF), P1 = ransum dengan $3 \%$ TLTF, P2 = ransum dengan $6 \%$ TLTF dan $\mathrm{P} 3=$ ransum dengan $9 \%$ TLTF.

\subsection{Pelaksanaan Penelitian}

Tabel 1.Komposisi Nutrisi Ransum Penelitian Hasil Perhitungan

\begin{tabular}{lccccc}
\hline Kandungan Nutrisi & \multicolumn{4}{c}{ Perlakuan } & \multirow{2}{*}{ Standar } \\
\cline { 1 - 5 } & P0 & P1 & P2 & P3 & \\
\hline ME(Kkal/Kg) & 2943 & 2901 & 2909 & 2915 & $2900-3200^{*}$ \\
CP (\%) & 20,4 & 19,5 & 19,6 & 19,0 & $18-20^{*}$ \\
SK (\%) & 4,1 & 5,3 & 6,4 & 7,6 & Maks 6** \\
LK (\%) & 6,3 & 5,2 & 5,0 & 4,8 & $2-7^{* *}$ \\
\hline dasarkan Standar Nasional Indonesia (2008) & & \\
Berdasarkan Standar Nasional Indonesia (2006) & &
\end{tabular}

\subsection{Variabel Yang Diamati}

\subsubsection{Analisis Kadar Protein Kasar}

Penentuan jumlah protein dalam ransum umumnya dilakukan menggunakan metode kjeldahl berdasarkan penentuan kadar nitrogen. Metode ini terbagi menjadi tiga tahap yaitu tahap destruksi, distilasi dan titrasi [6].

\subsubsection{Analisis Kadar Lemak Kasar}

Analisis bahan yang mengandung lemak pada umumnya dilakukan dengan memisahkan lemak dari matrik bahan menggunakan pelarut lemak dengan metod soxhlet. Pada hasil 
ekstraksi, ekstrak dalam labu dikerjakan dalam oven pada suhu $105^{\circ} \mathrm{C}$ hingga bobot tetap. Bobot residu dalam labu dinyatakan sebagai bobot lemak [6].

\subsubsection{Analisis Kadar Serat Kasar}

Serat kasar adalah residu dari bahan pakan yang direaksikan dengan asam dan basa panas. Serat kasar terdiri atas selulosa (50-80\%), hemiselulosa $20 \%$ dan lignin (10-50\%), yang hilang karena ekstraksi menggunakan asam sulfat dan natrium hidroksida dalam kondisi panas. Metode pelarutan dengan asam dan basa dalam keadaan tertutup pada suhu yang terkontrol disebut dengan proses digestion [7].

\subsection{Analisis Data}

Data yang diperoleh dianalisis dengan analisis sidik ragam, apabila terdapat hasil yang berbeda nyata $(\mathrm{P}<0,05)$ maka dilanjutkan dengan uji jarak nyata terkecil dari Duncan [8].

\section{Hasil Dan Pembahasan}

Ransum yang di uji dengan analisis proksimat di laboratorium dan dilanjutkan analisa sidik ragam, didapatkan hasil bahwa antara ransum yang ditambahkan tepung limbah tauge fermentasi dengan ransum tanpa penambahan tepung limbah tauge fermentasi menghasilkan perbedaan yang nyata $(\mathrm{P}<0,05)$, kecuali kandungan lemak kasar berbeda tidak nyata untuk semua perlakuan $(\mathrm{P}>0,05)$, seperti ditampilkan pada Tabel 3.1 di bawah ini.

Tabel 2.Kandungan Nutrisi Ransum Penelitian Hasil Analisa Proksimat

\begin{tabular}{cccccc}
\hline \multirow{2}{*}{ Nutrisi } & \multicolumn{4}{c}{ Perlakuan } & \multirow{2}{*}{ Standar } \\
\cline { 2 - 5 } & P0 & P1 & P2 & P3 & \\
\hline CP $(\%)^{2)}$ & $17,85^{\mathrm{b}}$ & $20,07^{\mathrm{a}}$ & $20,49^{\mathrm{a}}$ & $21,05^{\mathrm{a}}$ & $20 \min ^{\mathrm{*}} 18^{*}$ \\
LK $(\%)^{1)}$ & $2,69^{\mathrm{a}}$ & $3,13^{\mathrm{a}}$ & $3,19^{\mathrm{a}}$ & $2,67^{\mathrm{a}}$ & $2-7^{* *}$ \\
SK $(\%)^{1)}$ & $5,94^{\mathrm{c}}$ & $8,21^{\mathrm{b}}$ & $9,44^{\mathrm{ab}}$ & $9,88^{\mathrm{a}}$ & 6 maks $^{* *}$ \\
\hline
\end{tabular}

Sumber: ${ }^{1)}$ Hasil Analisis Laboratorium Ilmu-Ilmu Dasar Fakultas Pertanian Warmadewa, 2019

${ }^{2)}$ Hasil Analisis Laboratorium Ilmu dan Makanan Ternak Universitas Udayana, 2019

**Standar Nasional Indonesia , 2006

*Standar Nasional Indonesia, 2008

\subsection{Kadar Protein Kasar Ransum Penelitian}

Hasil penelitian (Tabel 3.1) menunjukkan bahwa ransum yang tidak mengandung tepung limbah tauge fermentasi mengandung kadar protein kasar paling rendah yaitu 17,85\% dan nilainya berbeda nyata $(\mathrm{P}<0,05)$ lebih rendah dari ransum yang mengandung tepung limbah tauge fermentasi, baik dengan P1, P2 maupun P3 yang nilainya berturut-turut 20,07 \%, 20,49 $\%$ dan 21,05 \%. Sedangkan ransum dengan perlakuan P1, P2, dan P3 berbeda tidak nyata $(\mathrm{P}>0,05)$ satu dengan lainnya. Ransum dengan kandungan tepung limbah tauge fermentasi mengandung protein kasar yang lebih tinggi. Hal ini karena kandungan protein kasar tepung limbah tauge fermentasi cukup tinggi yaitu 18,89\%, sedangkan yang belum difermentasi mengandung protein kasar sebesar 15,83 \%. Berdasarkan standar Nasional Indonesia [9], standar kebutuhan protein kasar ayam broiler fase finisher berkisar antara $18 \%-20 \%$. Ransum penelitian yang memenuhi standar ketentuan Standar Nasional Indonesia [9] dalam hal kandungan protein kasar adalah ransum $\mathrm{P} 1(20,07 \% \mathrm{CP})$, sedangkan kadar protein kasar 
ransum pada P2 dan P3 lebih tinggi dari standar, dan kadar protein kasar pada ransum P0 mengandung protein kasar yang lebih rendah dari standar Nasional Indonesia [9]. Kadar protein kasar pada tepung limbah tauge meningkat setelah adanya proses fermentasi, hal ini akibat dari peningkatan aktivitas mikroorganisme. [10] menyatakan bahwa peningkatan protein tersebut merupakan kontribusi protein sel tunggal dari sel mikroorganisme selama proses fermentasi.

\subsection{Kadar Lemak Kasar Ransum Penelitian}

Seperti disajikan pada Tabel 3.1, nilai lemak kasar ransum penelitian adalah 2,67\% $3,19 \%$. Kandungan lemak kasar dalam ransum penelitian nilainya berbeda tidak nyata $(\mathrm{P}>0,05)$ antara perlakuan (P0,P1,P2, dan P3) masing-masing sebesar 2,69 \%, 3,13\%, 3,19 $\%$, dan 2,67 \%. Kisaran kadar lemak kasar ransum penelitian 2,67\% - 3,19\%, nilai ini memenuhi ketentuan kandungan lemak kasar yang dikeluarkan SNI (2006) yaitu 2\% - 7\%. Dapat dijelaskan bahwa kandungan lemak kasar tepung limbah tauge fermentasi sangat rendah yaitu $0,73 \%$, dengan demikian kandungan sebanyak 3\%, 6\%, dan $9 \%$ tidak meningkatkan kadar lemak kasar ransum secara signifikan. Penjelasan ini didukung oleh pendapat dari [11] bahwa kandungan lemak ransum tergantung dari jenis bahan pakan penyusun ransum.

\subsection{Kadar Serat Kasar Ransum Penelitian}

Hasil penelitian (Tabel 3.1) menunjukkan kadar serat kasar ransum P0 (5,94\%) berbeda nyata $(\mathrm{P}<0,05)$ dibandingkan kadar serat kasar pada ransum $\mathrm{P} 1, \mathrm{P} 2$, dan $\mathrm{P}$ 3. Kadar serat kasar ransum pada $\mathrm{P} 1(8,21 \%)$ berbeda nyata lebih rendah $(\mathrm{P}<0,05)$ dari ransum $\mathrm{P} 3(9,88 \%)$ tetapi berbeda tidak nyata $(\mathrm{P}>0,05)$ dengan ransum pada $\mathrm{P} 2(9,44 \%)$. Hal ini dapat dijelaskan karena tepung limbah tauge fermentasi secara absolut masih mengandung serat kasar yang cukup tinggi yaitu $21,80 \%$, walaupun sudah mengalami penurunan dibandingkan dengan yang belum difermentasi kandungan serat kasarnya 41,15\% [4]. Kemungkinan pada proses fermentasi, senyawa kimia serat kasar yang kompleks telah dilemahkan dan menjadi senyawa yang lebih sederhana yang lebih mudah dicerna oleh unggas. Senada dengan pernyataan [12] bahwa pada proses fermentasi silase serat kasar terhidrolisis menjadi senyawa-senyawa yang lebih sederhana.

Serat kasar adalah karbohidrat yang hampir tidak dapat dicerna dalam organ perut ternak non ruminansia( unggas ), yang terdiri dari senyawa selulosa, hemiselulosa, dan lignin tetapi masih tetap diperlukan untuk menjaga gerak peristaltik usus [13]. Batas maksimal kandungan serat kasar dalam ransum unggas (broiler fase finisher) adalah maksimal 7\% [1]. Bila merujuk batasan tersebut, ransum penelitian hasil analisa proksimat mengalami kelebihan kandungan serat kasar, tetapi kemungkinan ikatan senyawanya sudah menjadi lebih sederhana yang akan lebih mudah dicerna dalam saluran pencernaan ayam.

\section{Kesimpulan}

Berdasarkan hasil penelitian dapat disimpulkan bahwa Ransum ayam broiler fase finisher yang mengandung tepung limbah tauge fermentasi mengalami peningkatan kandungan protein kasar, serta serat kasar , dibandingkan dengan ransum yang tidak mengandung tepung limbah tauge fermentasi. Ransum penelitian yang paling mendekati standar kebutuhan ayam broiler fase finisher adalah ransum yang mengandung $6 \%$ tepung limbah tauge fermentasi karena kualitas kimia ransum seperti protein kasar, dan lemak kasar berada pada batas 
standar yang ditetapkan SNI (2006) dan SNI (2008).Dari hasil penelitian dapat disarankan bahwa perlu melakukan fermentasi tepung limbah tauge dengan waktu yang lebih lama supaya kandungan serat kasar nya menjadi lebih rendah sehingga diharapkan serat kasar ransum sesuai kebutuhan ayam broiler fase finisher.

\section{Ucapan Terima Kasih}

Kami mengucapkan terima kasih kepada Lembaga Penelitian Universitas Warmadewa yang telah memberikan dana untuk melakukan penelitian ini, kepada Fakultas Pertanian dan Prodi Peternakan Universitas Warmadewa yang telah memberikan ijin dan fasilitas untuk melakukan penelitian, serta kepada rekan-rekan dosen, karyawan dan mahasiswa Fakultas Pertanian Universitas Warmadewa yang telah membantu terlaksananya penelitian ini sehinga selesai tepat waktu.

\section{References}

[1] Standar Nasional Indonesia. 2006. SNI 01-3931-2006. Pakan Ayam Ras Pedaging Masa Akhir. Badan Standar Nasional Indonesia.

[2] Nasruddin. 2010. Komposisi Nutrisi Ransum Ayam Ras Pedaging Masa Akhir (Broiler Finisher) dari Beberapa Bahan Pakan Lokal. Dinamika Penelitian BIPA. Vol.21. No. 38.

[3] Yulianto, J. 2010. Pengaruh Penggunaan Kulit Kecambah Kacang Hijau dalam Ransum terhadap Kecernaan Bahan Kering dan Organik pada Kelinci Keturunan Vlaams reus Jantan. Fakultas Pertanian Universitas Sebelas Maret. Surakarta. (Skripsi).

[4] Christiana, N. 2012. Efisiensi dan Kecernaan Serat Ransum Mengandung Limbah Tauge pada Kelinci Lokal Jantan Masa Pertumbuhan. Fakultas Peternakan Institut Pertanian Bogor. (Skripsi).

[5] Rahayu, S., D. Diapari., D. S. Wandito., \& W.W. Ifafah. 2010. Survey Potensi Ketersediaan Limbah Tauge sebagai Pakan Ternak Alternatif di Kotamadya Bogor. Laporan Penelitian. Bogor. (ID): Institut Pertanian Bogor.

[6] Association Official Analytical Chemistry [AOAC]. 2005. Official Method of Analysis, 18 th. Ed. Maryland (US): AOAC International.

[7] Sudarmadji, S., Haryono, B., Suhardi. 1996. Prosedur untuk Bhan Makanan dan Pertanian. Liberty. Yogyakarta

[8] Steel R.G. D dan J. H Torrie. 1995. Prinsip dan Prosedur Statistik. Suatu Pendekatan Biometrik. Edisi Kedua. Gramedia, Jakarta.

[9] Standar Nasional Indonesia. 2008. SNI 8173.3 : 2015. Pakan Ayam Ras Pedaging (Broiler)bagian 3: Masa Akhir (Finisher). Badan Standar Nasional Indonesia.

[10] Mahmilia, F. 2005. Perubahan Nilai Gizi Tepung Enceng Gondok Fermentasi dan Pemanfaatannya sebagai Ransum Ayam Pedaging. Jurnal Loka Penelitian Kambing Potong. Sumatera Utara. JITV 10(2):91-94.

[11] Kurniati. 2016. Kandungan Lemak Kasar, Bahan Organik, dan Bahan ekstrak Tanpa Nitrogen Silase Pakan Lengkap Berbahan Utama Batang Pisang (Musa paradisiaca) dengan Lama Incubasi yang Berbeda. Skripsi Sarjana. Fakultas Peternakan. Universitas Hasanuddin. Makasar.

[12] Novianto, N., Lestari, S., dan Hanggita, RJ. 2012. Karakteristik Kimia dan Mikrobiologi Silase Keong Mas (Pomacea canaliculata) dengan Penambahan Asam Format dan Bakteri Asam Laktat 3 B104. Jurnal Fistech. 1(1):55-68.

[13] Piling, W.G. dan S. Djojosoebagio. 2002. Fisiologi Nutrisi. Edisi Kedua. Press Jakarta. 